\title{
Relationship between Cool Coma and Heat Coma Temperatures in the Oceanic Sea Skaters Halobates Collected near the Sumatra Island in the Indian Ocean
}

\author{
Takahiro Furuki ${ }^{1}$, Noritomo Umamoto ${ }^{1}$, Wataru Ohoka ${ }^{2}$, Mitsuru Nakajo ${ }^{3}$, Chihiro Katagiri ${ }^{4}$, \\ Sam Wouthuyzen ${ }^{5}$, Tetsuo Harada ${ }^{1}$ \\ ${ }^{1}$ Laboratory of Environmental Physiology, Graduate School of Integrated Arts and Sciences, Kochi University, \\ Kochi, Japan; ${ }^{2}$ Laboratory of Human Health Science, Graduate School of Medicine, Kyoto University, Japan; \\ ${ }^{3}$ Laboratory of Science Education, Graduate School of Integrated Arts and Sciences, Kochi University, Kochi, \\ Japan; ${ }^{4}$ Tokyo Denki University, Tokyo, Japan; ${ }^{5}$ Research Center for Oceanography, Indonesian Institute of \\ Science, LIPI, Jakarta, Indonesia
}

Correspondence to: Tetsuo Harada, haratets@kochi-u.ac.jp

Keywords: Oceanic Sea Skaters, Cool and Heat Comas, Recovery Seconds from Temperature Comas, Madden-Julian Oscillation, Precipitation

Received: April 2, 2017 Accepted: May 24, $2017 \quad$ Published: May 27, 2017

Copyright $\odot 2017$ by authors and Scientific Research Publishing Inc.

This work is licensed under the Creative Commons Attribution International License (CC BY 4.0).

http://creativecommons.org/licenses/by/4.0/

\section{(c) (1) Open Access}

\section{ABSTRACT}

In the cruise, MR15-04 by R/V MIRAI, the samplings by the neuston net were performed in $23^{\text {rd }}$ November to $14^{\text {th }}$ December 2016 and three species of Halobates ( $H$. germanus, $H$. micans, $H$. sp) were used for the temperature tolerance experiments after the collection. The neuston net was towed three times $(3 \times 15 \mathrm{~min})$ on the starboard side of R/V MIRAI on the water surface with ship speed of 2 knot to water every 3 nights (19:00 - 20:00) at the fixed point in the south-western direction which was located at $50 \mathrm{~km}$ from the Sumatra island $\left(4^{\circ} 03^{\prime} \mathrm{S}-4^{\circ} 05^{\prime} \mathrm{S}, 101^{\circ} 53^{\prime} \mathrm{E}\right)$ in the Indonesia. Experiments on cool coma and heat coma were performed on the three species. Seconds for recovery from cool coma and heat coma were also examined on the Halobates in this study. Cool coma temperatures, gap temperature needed (temperature from the adapted temperature) for the cool coma and seconds for the recover from cool coma ranged $13.0^{\circ} \mathrm{C}$ to $25.0^{\circ} \mathrm{C}, 3.1^{\circ} \mathrm{C}$ to $16.1^{\circ} \mathrm{C}, 1$ second to 4370 seconds, respectively. Heat coma temperature, gap temperature needed for the heat coma, seconds for the recover from heat coma ranged $29.4^{\circ} \mathrm{C}$ to $43.1^{\circ} \mathrm{C}, 1.9^{\circ} \mathrm{C}$ to $15.5^{\circ} \mathrm{C}, 2$ seconds to 6420 seconds, respectively. The higher temperature of cool coma temperature during the last five days was shown when Madden-Julian Oscillation has passed over the ship, R/V MIRAI than the previous 10 days in the adults of $H$. germanus collected at the fixed place neat to Sumatra island (One way ANOVA: F-value $=2.314, \mathrm{df}=7, \mathrm{p}=0.028$ ). Adults of un-described species, $H$. $\mathrm{sp}$ 
collected near to the Sumatra island, showed lower cool coma temperature [Mean \pm SD: 15.51 \pm 3.76 (9)] than those of $H$. germanus collected in the same place [16.96 \pm 2.57 (191)]. This lower cool coma temperatures shown by this un-described species might be related to that this species should be a "shore" species inhabiting shore water in which many precipitation could cause the decreased surface temperature from $30^{\circ} \mathrm{C}-31^{\circ} \mathrm{C}$ into about $25^{\circ} \mathrm{C}$. Most of adults which suffered from the cool coma recovered within 20 seconds, whereas adults which suffered heat coma at $38^{\circ} \mathrm{C}$ and $39^{\circ} \mathrm{C}$ needed more than 200 seconds for the recovery and many of those which did it at more than $40^{\circ} \mathrm{C}$ needed more than 1000 second and some ones did not recover at all. All adults who suffered at more than $43^{\circ} \mathrm{C}$ did not recover at all. There were significant and negative correlation between cool and heat coma temperatures shown by the adults of $H$. germanus. This correlation might imply a common physiological mechanism for lower and higher temperature tolerances for this species.

\section{INTRODUCTION}

Studies on temperature tolerance have been done about heat tolerance [1-4] and those on cool tolerance are very limited to studies by Furuki et al. [5], and Umamoto et al. [6] in sea skaters. There have been no studies which examined both heat and cool tolerances on the same population and at the same time in insects. Also there have been no studies which measured both recovery times from Cool Coma (CC) and Heat Coma (HC) in insects.

\subsection{Cross-Tolerance between Hardness to Lower and Higher Temperatures}

The cross tolerance in insects has been shown mainly between cold hardiness and drought hardiness in the crass, insects [7]. However, there have been only a few reports on the cross tolerance between low and high temperature hardiness. One example of these reports is on a fruit fly, Drosophila melanogaster [8]. Harada et al. [9] reported that a fresh water species of water strider, Aquarius paludum paludum, developed the cross tolerance as lower and higher lethal temperatures via the growth under a relatively low ambient temperature of $20^{\circ} \mathrm{C}$ than a higher temperature of $25^{\circ} \mathrm{C}$, as a temperature acclimation affect. However, there have no studies on whether there is a cross tolerance between lower temperature and higher temperature in the sea skaters. This study, first, aims to answer this question.

\subsection{Madden-Julian Oscillation and Resistance to Lower Temperature, Shown by Sea Skaters}

The chief scientist of the cruise, MR11-07 and a Meteorologist, Dr. Kunio Yoneyama kindly gave us a very important comment that the sea surface of $5^{\circ} \mathrm{S}-10^{\circ} \mathrm{S}, 75^{\circ} \mathrm{E}-95^{\circ} \mathrm{E}$ is very special area because intra-seasonal temperature variations in this area are highest in the world open oceans. This special area is predicted to be a key site for developing a large low pressure mass due to the Madden Julian Oscillation (MJO) (Yoneyama, personal communication [10]. This large low pressure area with a diameter of about $12,000 \mathrm{~km}$ can move eastward taking 30 to 60 days into the middle of the Pacific Ocean in relation with the occurrence of El Niñoand La Niña phenomena [11-13]. In this study, the Madden Julian Oscillation has come over the R/V MIRAI during the cruise, MR15-04 in the last week during the sampling 3 weeks at the fixed point of $04^{\circ} 00^{\prime} \mathrm{S} 102^{\circ} 00^{\prime} \mathrm{E}$ located $50 \mathrm{~km}$ in the southern-eastern direction from Sumatra Island. The second aim is to clarify whether the cool tolerance of adult $H$. germanus can get the influence from coming over of the Madden Julian Oscillation.

\subsection{Tolerance to Lower or Higher Temperature in Oceanic Species and Shore Species of Sea Skaters}

On the temperature tolerance of oceanic sea skaters, several studies have been done from multiple 
points of view. For example, difference in the latitude distribution can be related to the difference in heat and cool tolerance in the three oceanic species (Harada et al., unpublished). Adult Halobates sericeus which has wide latitude distribution of $35^{\circ} \mathrm{S}$ to $40^{\circ} \mathrm{N}$ showed higher resistances to both higher lower and higher temperatures than the other two species of $H$. micans and $H$. germaus which had only narrow distribution mainly from $15^{\circ} \mathrm{S}$ to $15^{\circ} \mathrm{S}$, because $H$. sericeus has suffered higher temperature fluctuations due to seasons in higher latitude places [1]. In $H$. sericeus, populations which have higher influence from the Kuroshio current showed higher resistance to lower temperature than other population which has little influence from current [5]. Umamoto et al. [6] showed that adult $H$. germanus which inhabit $8^{\circ} \mathrm{N} 138^{\circ} \mathrm{E}$ in the tropical Pacific Ocean showed higher resistance to lower temperature than the population inhabiting $12^{\circ} \mathrm{N} 135^{\circ} \mathrm{E}$ because higher influence from heavy rain fall, which accompanies decrease of surface air temperature by $5^{\circ} \mathrm{C}$ in the sampling point at $8^{\circ} \mathrm{N} 138^{\circ} \mathrm{E}$ [14]. Frequent experiences of exposing to this temperature decreases due to rain falls may select the higher resistance to lower temperature. However, there has no data on the shore species in Halobates and also no data on the comparison between oceanic species and shore species in Halobates. The third aim is to clarify the comparison: the hypothesis is that shore species may show higher resistance to lower or higher temperature because the shore species can be hypothesized to have higher resistance to the decreased temperature due to rain fall than the oceanic species.

\section{MATERIALS AND METHODS}

\subsection{Samplings}

Samplings were performed in $6^{\text {th }}-16^{\text {th }}$ March, 2010 with a IKMT-NET $(10 \mathrm{~m}$ long and with width of the opening of about $3 \mathrm{~m}$ ). The IKMT-NET was trailed for $1 \mathrm{~min}$. On the sea surface at 44 stations located $3^{\circ} \mathrm{N}-1^{\circ} \mathrm{S}, 120^{\circ} \mathrm{E}-125^{\circ} \mathrm{E}$. in the Celebes Sea and the Tomini Gulf on the back of R/V HAKUHOMARU (3991 t) which is owned by JAMSTEC (Japan Agency for Marine-earth Science and Technology) during the science cruise, KH-09-05-Leg 7 organized by Ocean Research Institute, The University of Tokyo. The trailing on the water surface was performed for 1 min with the ship speed of $2.0-2.5$ knot to the sea water. Surface area which was swept by IKMT-NET was evaluated as an expression of [ $2.25 \mathrm{knot} \times 1800 \mathrm{~m} / \mathrm{h}+$ $0.3 \mathrm{~m} / \mathrm{sec} \times 3600) \times 1 / 60 \times 3$ ]. The area which was swept by the IKMT-NET during the trailing of $1 \mathrm{~min}$ on the water surface can be estimated as the value of $256.5 \mathrm{~m}^{2}$ per one sweeping on average.

Samplings were performed every three days in $20^{\text {th }}$ November 2015 to $14^{\text {th }}$ December 2015 in the area of $4^{\circ} \mathrm{S}-7^{\circ} \mathrm{S}, 101^{\circ} \mathrm{E}-103^{\circ} \mathrm{E}$ with a Neuston NET ( $6 \mathrm{~m}$ long and with diameter of $1.3 \mathrm{~m}$ ) in the shore area 50 $\mathrm{km}$ far from the Sumatra island of the Indonesia during the cruise MR15-04 (Figure 1), [15]. The Neuston NET was trailed for $15 \mathrm{~mm} \times 3$ times as one set-trial on the sea surface per one night. Nine set-trials have been performed in total from the starboard side of R/V MIRAI (8687 t) which is owned by the JAMSTEC. The 9 set-trials were performed in total during this cruise with the ship speed of 2.0 knot to the sea water. The 15 min-towing was repeated 2 times in each station. Surface area which was swept by Neuston NET was evaluated as an expression of [flow-meter value $\times 1.3 \mathrm{~m}$ of width of the Neuston NET].

\subsection{Treatments of Specimens after the Samplings and before the Experiments}

Sea skaters trapped in the grey plastic bottle located and fixed at the end of Neuston NET were paralyzed with the physical shock due to the trailing of the Neuston NET. Such paralyzed sea skaters were transferred on the surface of paper towel to respire. Then, the paralysis of most of the individuals was discontinued within $20 \mathrm{~min}$. When sea skaters were trapped in the jelly of jelly fishes, the jelly was removed from the body of sea skaters very carefully and quickly by hand for recovery out of the paralysis.

Adults which recovered out of the paralysis were moved on the sea water in the aquaria set in the laboratory before the Cool Coma and Heat Coma Experiments (CCE, HCE). Many white cube aquaria (30 $\mathrm{cm} \times 30 \mathrm{~cm} \times 40 \mathrm{~cm}$ ) were used in the laboratory of the ship for rearing the adults that had been recovered out of the paralysis due to the trailing. Each aquarium contained ten to thirty adults of Halobates. Both the room temperature and sea water temperature in the aquaria were kept at $29^{\circ} \mathrm{C} \pm 2^{\circ} \mathrm{C}$. For $11-12$ hours after the collection, sea skaters were kept in the aquaria without foods. The adults kept for the $11-12$ 


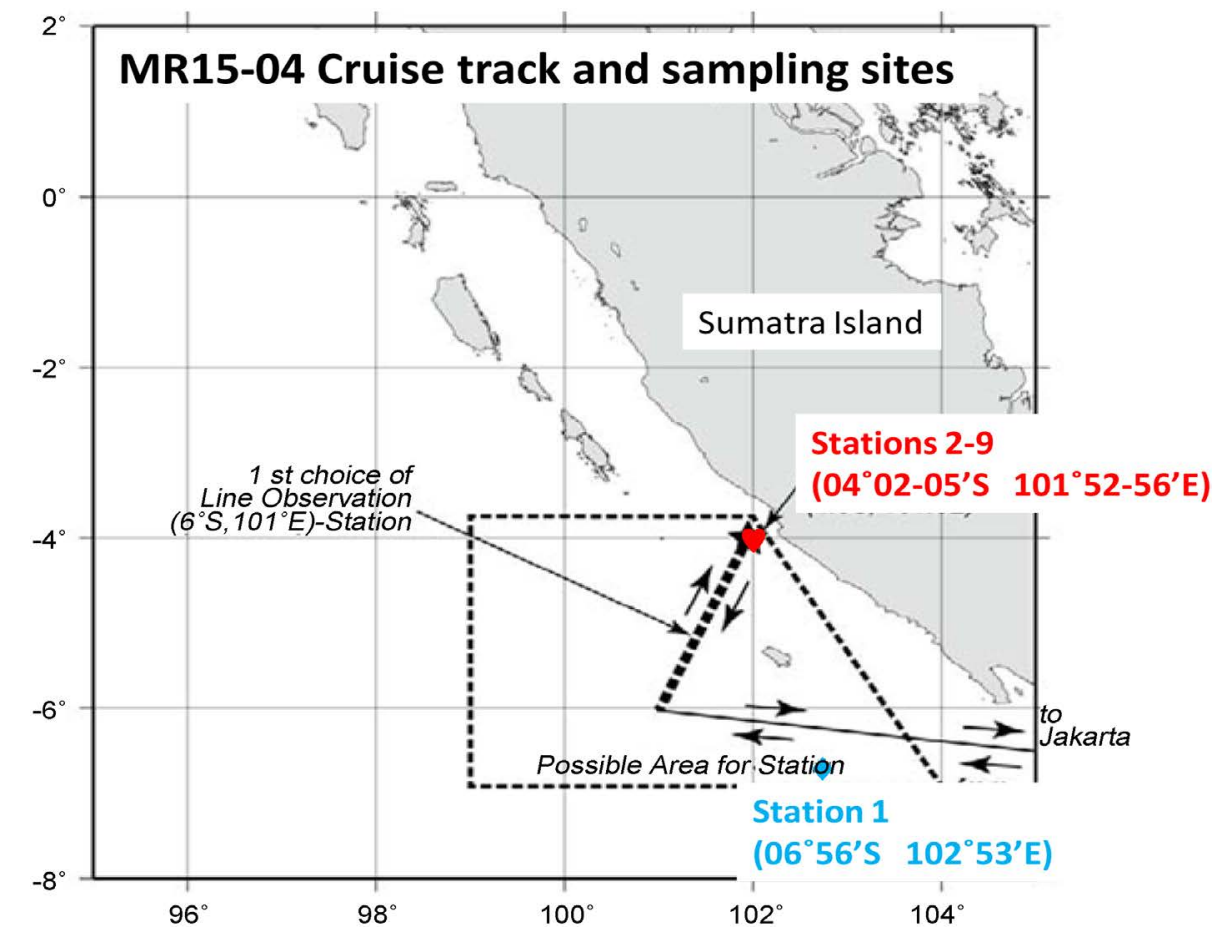

Figure 1. Schematic presentation of the sampling points in the shore area in the Indian Ocean, near to the Sumatra Island in the Indonesia during the cruise of MR15-04.

hours after the collection were used for Cool and Heat Coma experiments. When the adults were used for the CCE and HCE in the second day or thereafter from the samplings, the adults were fed on adult flies, Lucillia illustris. However, the adults used for the experiments were starved for the previous $11-12$ hours just before CCE and HCE in any time. Foods were given and replaced to new ones every 6 - 12 hours, and sea water in the aquaria was replaced by the new one three times at 8:00, 13:00 and 18:00 for the avoidance from water pollution due to the foods.

\subsection{Cool Coma Experiments (CCE) and Heat Coma Experiments (HCE)}

Twelve or thirteen adults were moved from the cube aquaria in which those specimen had been kept, to the two machines as Low Temperature Thermostatic Water Bathes (Thomas: T22LA) $(55 \mathrm{~cm} \times 40 \mathrm{~cm} \times$ $35 \mathrm{~cm}$ ). Temperature was gradually decreased or increased (at a rate of $1^{\circ} \mathrm{C}$ per $3-5 \mathrm{~min}$ ) by $1^{\circ} \mathrm{C}$ every 15 min by the automatic cooling/heating system of the water bathes till the cool or heat temperature coma which occurs in all the experimental specimens.

Temperature was very precisely controlled by automatic thermo-stat system of the water bathes. Temperatures at which Cool Comas or Heat Comas occur were recorded. Cool Coma Temperature [CCT] or Heat Coma Temperature [HCT] was estimated as follows: when the ventral surface of the body was caught by sea water film and the ability to skate was lost, or when abnormal postures on the sea-water were observed-for example, one leg sank into the water, the body was upside down, or the mid-leg moved behind and attached to hind leg.

\subsection{Recovery Experiments}

When they suffered Cool Coma (CC) or Heat Coma (HC), the experimental specimens were transferred from the Experimental Water Bathes to the sea water in the round shaped transparent small containers $\left(17 \mathrm{~cm}\right.$ diameter and $6 \mathrm{~cm}$ height) with fresh sea waters with height of $1 \mathrm{~cm}$ at $29^{\circ} \mathrm{C} \pm 2{ }^{\circ} \mathrm{C}$ of air 
and water temperatures. They were observed for two hours to judge the recovery from these comas and measure the time (seconds) for the recovery. Any individuals which had not recovered from the comas for 7200 seconds have been no more recovered at all. The recovery was judged when the specimen began to skate normally on the surface. All individuals who recovered from the comas did the continuous "cleaning behavior" using all 6 legs before the recovery.

\section{RESULTS}

\subsection{Samplings in the Tomini Bay and Celebes Sea in the Indonesia}

At 8 stations of 21 sampling stations in total in the Tomini Bay, Halobates sp. 1 was collected. On the other hand, $H$. germanus and $H$. micans were collected at only one station (St. 29 for H. germanus, St 32 for $H$. micans) of 13 stations in the Celebes Sea. Water and air temperatures were both similar and $31^{\circ} \mathrm{C} \pm$ $2^{\circ} \mathrm{C}$ at Stations in Tomini Bay and $28^{\circ} \mathrm{C} \pm 2^{\circ} \mathrm{C}$ in the Celebes Sea.

\subsection{Samplings in the Shore Area $50 \mathrm{~km}$ Far from the Sumatra Island in the Direction of Southern-Eastern Direction}

The samplings of Halobates were performed as one set trial ( $15 \mathrm{~min} \times 3$ tows) per night and in total 9 nights in the tropical 2 stations in the eastern Indian Ocean showed that 12 - 330 individuals per the one-set trial of four species of Halobates germanus, $H$. micans, $H$. princeps and un-described and relatively large species, $H$. sp 2 (Table 1) [15] (about $5 \mathrm{~cm}$ of body length of adults with "gourd" like shape). This is probably new species due to a morphological study and precise comparison with all the 71 species described in the Appendix as the Key of the identification of Halobates Eschsholtz: [16]. These four species were collected at the stations within $04^{\circ} 00^{\prime} \mathrm{S}-07^{\circ} 00^{\prime} \mathrm{S}, 101^{\circ} 00^{\prime} \mathrm{E}-103^{\circ} 00^{\prime} \mathrm{E}$. At the fixed station (Station 2: $04^{\circ} 02^{\prime} \mathrm{S} 101^{\circ} 53^{\prime} \mathrm{E}$ ) located about $50 \mathrm{~km}$ in the southern-western direction from the shore of Sumatra Island, Indonesia, the four species of Halobates were collected. However, $H$. germanus was dominant species in this fixed station.

\subsection{Cool Coma Experiments (CCE), Heat Coma Experiments (HCE) and Recovery Times from CC and HC (RTCC and RTHC)}

All the individuals of $H$. germanus (Table 2(a) and Table 2(b)) which were collected at Stations 1 - 2 and had been completely recovered from the paralysis by the physical shock due to the Neuston net sweeping during MR15-04 cruise were used for CCE and HCE. Cool-Coma Temperature (CCT), Gap Temperature for Cool Coma (GTCC) and Recovery Time from Cool-Coma (RTCC) were ranged $13.0^{\circ} \mathrm{C}$ to $25.0^{\circ} \mathrm{C}$ and $3.1^{\circ} \mathrm{C}$ to $16.1^{\circ} \mathrm{C}$, 1 second to 4370 seconds, respectively. On the other hand, Heat-Coma

Table 1. Results of samplings of oceanic sea skaters inhabiting eastern tropical Indian Ocean (station 1: $06^{\circ} 56^{\prime} \mathrm{S}-06^{\circ} 58^{\prime} \mathrm{S} 102^{\circ} 53^{\prime} \mathrm{E}-102^{\circ} 54^{\prime} \mathrm{E}$; station 2: $04^{\circ} 02^{\prime} \mathrm{S}-04^{\circ} 06^{\prime} \mathrm{S} 101^{\circ} 52^{\prime} \mathrm{E}-101^{\circ} 55^{\prime} \mathrm{E}$ ) [16].

\begin{tabular}{ccccccccc}
\hline A. $06^{\circ} 56^{\prime} \mathrm{S}-06^{\circ} 58^{\prime} \mathrm{S}$ & \multicolumn{2}{c}{ Total } & H. m. & H. g. & H. s. $H . p$ & H. sp & Arena swept $\left(\mathrm{km}^{2}\right)$ \\
\cline { 2 - 9 } $102^{\circ} 53^{\prime} \mathrm{E}-102^{\circ} 54^{\prime} \mathrm{E}($ Station 1$)$ & Females & Males & & & & & \\
\hline Number & 29 & 17 & 0 & 46 & 0 & 0 & 0 & $744,055 \times 10^{-8}$ \\
Density & 3897.6 & 2284.8 & 0 & 6182.3 & 0 & 0 & 0 & \\
\hline B. $04^{\circ} 02^{\prime} \mathrm{S}-04^{\circ} 06^{\prime} \mathrm{S}$ & \multicolumn{2}{c}{ Total } & H. m. & H. g. & H. s. H. $p$ H. sp 2 Arena swept $\left(\mathrm{km}^{2}\right)$ \\
\cline { 2 - 9 } $101^{\circ} 52^{\prime} \mathrm{E}-101^{\circ} 56^{\prime} \mathrm{E}$ (Stations 2 ) & Females & Males & & & & & Females \\
\hline Number & 358 & 355 & 23 & 621 & 0 & 1 & 68 & $307,267 \times 10^{-7}$ \\
Density & $11,651.1$ & $11,553.5$ & 748.5 & $20,210.5$ & 0 & 32.5 & 2213.1 & \\
\hline
\end{tabular}


Table 2. (a) Comparison of Semi-Cool Coma Temperature (SCCT), Cool Coma Temperature (CCT), Gap Temperature for Cool Coma (GTHC), Recovery Time from Cool Coma (RTCC), Semi-Cool Coma Temperature (SHCT), Heat Coma Temperature (HCT), Gap Temperature for Heat Coma (GTHC) and Recovery Time from Heat Coma (RTHC) in Halobates germanus, between the individuals collected at two stations: one (A: $06^{\circ} 56^{\prime} \mathrm{S}-06^{\circ} 58^{\prime} \mathrm{S} 102^{\circ} 53^{\prime} \mathrm{E}-102^{\circ} 54^{\prime} \mathrm{E}$ : Station 1: Sampling 1) and another fixed one (B: $04^{\circ} 02^{\prime} \mathrm{S} 101^{\circ} 52^{\prime} \mathrm{E}-101^{\circ} 55^{\prime} \mathrm{E}$ : Station 2: Samplings 2 - 9) in this cruise. Experiments were performed in the period from $21^{\text {st }}$ November to $15^{\text {th }}$ December 2015 during this cruise, MR15-04, in the wet-lab 2 of R/V MIRAI. (b) Statistic analysis on the relationship of sex and stages to Semi-Cool Coma Temperature (SCCT), Cool Coma Temperature (CCT), Gap Temperature for Cool Coma (GTHC), Recovery Time from Cool Coma (RTCC) was performed using ANCOVA. Statistic analysis also was performed using ANOVA on the relationship of Semi-Cool Coma Temperature (SHCT), Heat Coma Temperature (HCT), Gap Temperature for Heat Coma (GTHC), and Recovery Time from Heat Coma (RTHC) to the two stations: one (A: $06^{\circ} 56$ 'S - $06^{\circ} 58^{\prime} \mathrm{S} 102^{\circ} 53^{\prime} \mathrm{E}$ $102^{\circ} 54^{\prime} \mathrm{E}$ : Station 1: Sampling 1) and another fixed one (B: $04^{\circ} 02^{\prime} \mathrm{S} 101^{\circ} 52^{\prime} \mathrm{E}-101^{\circ} 55^{\prime} \mathrm{E}$ : Station 2 : Samplings 2 - 9) in this cruise. Experiments were performed in the period from $21^{\text {st }}$ November to $15^{\text {th }}$ December 2015 during this cruise, MR15-04, in the wet-lab 2 of R/V MIRAI.

(a)

\begin{tabular}{ccccc}
\hline A: Station 1 & SCCT & CCT & GTCC & RTCC \\
\hline Adults & $15.28 \pm 1.65(13)$ & $15.05 \pm 1.74(13)$ & $12.95 \pm 1.74(13)$ & $908.00 \pm 2086.38(13)$ \\
5th instars & $13.75 \pm 0.35(2)$ & $13.75 \pm 0.35(2)$ & $14.25 \pm 0.35(2)$ & $3602.00 \pm 5088.34(2)$ \\
4th instars & $18.05 \pm 5.59(2)$ & $18.05 \pm 5.59(2)$ & $9.95 \pm 5.59(2)$ & $3690.00 \pm 4963.89(2)$ \\
Total & $15.42 \pm 2.28(17)$ & $15.25 \pm 2.35(17)$ & $12.75 \pm 2.35(17)$ & $1552.24 \pm 2802.97(17)$ \\
\hline B: Station 2 & SCCT & CCT & GTCC & RTCC \\
\hline Adults & $17.36 \pm 2.39(142)$ & $17.20 \pm 2.48(142)$ & $10.93 \pm 2.59(142)$ & $24.12 \pm 93.21(142)$ \\
5th instars & $16.92 \pm 2.60(27)$ & $16.67 \pm 2.66(27)$ & $11.51 \pm 2.69(27)$ & $229.96 \pm 849.10(27)$ \\
4th instars & $18.95 \pm 2.80(4)$ & $18.95 \pm 2.80(4)$ & $9.50 \pm 2.56(4)$ & $19.5 \pm 8.39(4)$ \\
Total & $17.31 \pm 2.44(173)$ & $17.13 \pm 2.54(173)$ & $10.99 \pm 2.61(173)$ & $56.17 \pm 348.89(173)$ \\
\hline Station 2 & SHCT & HCT & GTHC & RTHC \\
\hline Adults & $39.80 \pm 2.58(125)$ & $39.83 \pm 2.58(125)$ & $11.74 \pm 2.55(125)$ & $3175.78 \pm 3253.78(125)$ \\
5th instars & $38.19 \pm 3.68(14)$ & $38.19 \pm 3.68(14)$ & $9.85 \pm 3.50(14)$ & $1253.14 \pm 2534.95(14)$ \\
4th instars & $41.10 \pm 0.14(2)$ & $41.10 \pm 0.14(14)$ & $12.20 \pm 0.14(2)$ & $7200 \pm 0.00(2)$ \\
Total & $39.68 \pm 2.73(141)$ & $39.69 \pm 2.72(141)$ & $11.56 \pm 2.69(141)$ & $3040.00 \pm 3249.01(139)$ \\
\hline
\end{tabular}

(b)

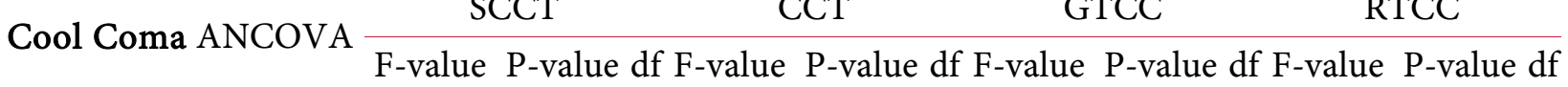

\begin{tabular}{cccccccccccccc}
\hline Stations & 9.159 & 0.003 & 1 & 8.364 & 0.004 & 1 & 7.276 & 0.008 & 1 & 43.160 & $<0.001$ & 1 \\
Stages & 0.48 & 0.827 & 1 & 0.124 & 0.725 & 1 & 0.143 & 0.706 & 1 & 6.564 & 0.011 & 1 \\
\hline & \multicolumn{2}{c}{ SHCT } & \multicolumn{2}{c}{ HST } & \multicolumn{2}{c}{ GTHC } & \multicolumn{4}{c}{ RTHC }
\end{tabular}

Heat Coma ANOVA $\mathrm{F}$-value P-value df F-value P-value df F-value P-value df F-value P-value df $\begin{array}{lllllllllllll}\text { Stages } & 2.599 & 0.078 & 2 & 2.605 & 0.078 & 2 & 3.275 & 0.041 & 2 & 4.034 & 0.020 & 2\end{array}$ 
Temperature (HCT), Gap Temperature for Heat Coma (GTHC) and Recovery Time from Heat-Coma (RTHC) were ranged $29.4^{\circ} \mathrm{C}$ to $43.1^{\circ} \mathrm{C}, 1.9^{\circ} \mathrm{C}$ to $15.5^{\circ} \mathrm{C}$ and 2 second to 6420 seconds, respectively. There were no significant differences in both cool hardiness and heat hardiness between sexes and nor between species (Table 3(a) and Table 3(b)).

Table 3. (a) Semi Heat-Coma Temperature (SHCT), Heat Coma Temperature (HCT), Gap Temperature for Heat Coma (GTHC), Recovery time from Heat Coma (RTHC) in Halobates micans, $H$. germanus and $H$. sp (un-described species: Harada et al., 2016) and comparison of these values between males and females in all samples (station 1: $06^{\circ} 56^{\prime} \mathrm{S}-06^{\circ} 58^{\prime} \mathrm{S} 102^{\circ} 53^{\prime} \mathrm{E}-102^{\circ} 54^{\prime} \mathrm{E}$; station 2 [samples 2 - 9]: $04^{\circ} 02^{\prime} \mathrm{S}-04^{\circ} 06^{\prime} \mathrm{S} 101^{\circ} 52^{\prime} \mathrm{E}-101^{\circ} 55^{\prime} \mathrm{E}$ ) in this cruise of MR15-04/experiments were performed in the period from $21^{\text {st }}$ November to December 2015 during this cruise in the wet lab 2 of R/V MIRAI. (b) Statistic analysis on Semi Heat-Coma Temperature (SHCT), Heat Coma Temperature (HCT), Gap Temperature for Heat Coma (GTHC), Recovery time from Heat Coma (RTHC) in Halobates micans, $H$. germanus and $H$. sp (un-described species: Harada et al., 2016) ANCOVA analyses on sex and species effects were used.

(a)

\begin{tabular}{ccccc}
\hline A: Cool Coma & SCCT & CCT & GTCC & RTCC \\
\hline Halobates germanus & $17.14 \pm 2.47(191)$ & $16.96 \pm 2.57(191)$ & $11.14 \pm 2.63(191)$ & $189.05 \pm 976.90(191)$ \\
H. sp & $16.44 \pm 3.28(9)$ & $15.51 \pm 3.76(9)$ & $12.54 \pm 3.71(9)$ & $87.11 \pm 132.16(9)$ \\
Females (adults) & $17.26 \pm 2.51(91)$ & $17.04 \pm 2.64(91)$ & $11.02 \pm 2.70(91)$ & $160.78 \pm 829.95(91)$ \\
Males (adults) & $16.85 \pm 2.66(67)$ & $16.89 \pm 2.29(67)$ & $11.39 \pm 2.58(67)$ & $14.78 \pm 21.76(67)$ \\
\hline B: Heat Coma & SCCT & CCT & GTCC & RTCC \\
\hline Halobates germanus & $39.68 \pm 2.73(141)$ & $38.35 \pm 2.73(141)$ & $11.56 \pm 2.69(141)$ & $3249.01 \pm 3249.01(139)$ \\
H. micans & $38.12 \pm 3.44(17)$ & $38.35 \pm 3.42(17)$ & $10.44 \pm 3.37(17)$ & $4372.1 \pm 3499.07(17)$ \\
Females (adults) & $39.76 \pm 2.64(90)$ & $39.76 \pm 2.64(90)$ & $11.68 \pm 2.60(90)$ & $3733.65 \pm 3300.93(89)$ \\
Males (adults) & $39.83 \pm 2.53(44)$ & $39.83 \pm 2.53(44)$ & $11.78 \pm 2.53(44)$ & $2226.65 \pm 3009.61(43)$ \\
\hline
\end{tabular}

(b)

\begin{tabular}{cccccccccccccccc} 
A: ANCOVA (Cool Coma) & \multicolumn{3}{c}{ SCCT } & \multicolumn{3}{c}{ CCT } & \multicolumn{3}{c}{ GTCC } & \multicolumn{4}{c}{ RTCC } \\
\cline { 2 - 12 } & \multicolumn{2}{c}{ F-value P-value df F-value P-value df F-value P-value df F-value P-value df } \\
Species & 1.627 & 0.204 & 1 & 3.163 & 0.077 & 1 & 2.897 & 0.091 & 1 & 0.058 & 0.810 & 1 \\
Sex & 0.334 & 0.564 & 1 & 0.143 & 0.706 & 1 & 0.387 & 0.535 & 1 & 2.032 & 0.156 & 1 \\
\hline
\end{tabular}

One-Way ANOVA $\quad$ F-value P-value df F-value P-value df F-value P-value df F-value P-value df

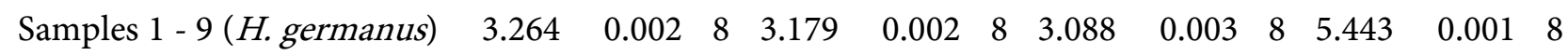
$\begin{array}{llll} & \text { SHCT } & \text { HCT } & \text { GTHC }\end{array}$

F-value P-value df F-value P-value df F-value P-value df F-value P-value df

\begin{tabular}{ccccccccccccc}
\hline Species & 0.556 & 0.457 & 1 & 0.560 & 0.456 & 1 & 0.222 & 0.638 & 1 & 0.332 & 0.565 & 1 \\
Sex & 0.003 & 0.958 & 1 & 0.002 & 0.961 & 1 & 0.024 & 0.878 & 1 & 5.909 & 0.016 & 1 \\
\hline
\end{tabular}


Most of adult individuals which suffered from cool comas have recovered within 20 seconds (Table 3(a)) (Figure 2), whereas the recovery time was significantly longer when they recovered from heat coma (HC) which occurred at the temperature higher than $38^{\circ} \mathrm{C}$ (Table 3(a)) (Figure 3). Some of the individuals which suffered from $\mathrm{HC}$ at $40^{\circ} \mathrm{C}-42^{\circ} \mathrm{C}$ did not recover. When they suffered from $\mathrm{HC}$ at $43^{\circ} \mathrm{C}$, all individuals did not recover any more (Figure 3). Males recovered from $\mathrm{HC}$ with longer seconds than females (Table 3(a)). The recovery time from Cool Coma by adult $H$. germanus was significant shorter than that by $5^{\text {th }}$ instars, whereas the recovery time from Heat Coma by the adults was significantly longer than that by the fifth instars (Table 2 (a) and Table 2(b)). The exposure to around $40^{\circ} \mathrm{C}$ might make some injury in neuro-physiological function for sea skaters, whereas that to around $15^{\circ} \mathrm{C}$ seems to make a moderate and temporary damage in this function and such damage would be possible to be soon recovered.

\subsection{Change for the 20 Days in the Cool Coma Temperature and during the Latter 10 Days When Madden Julian Oscillation Has Come over the Fixed Sampling Point}

During 20 days at a fixed station, cool tolerance of adult Halobate sgermanus was changed significantly (One-Way ANOVA: $\mathrm{df}=7, \mathrm{~F}=2.67, \mathrm{p}=0.013$ ) (Figure 4). When Madden-Julian Oscillation

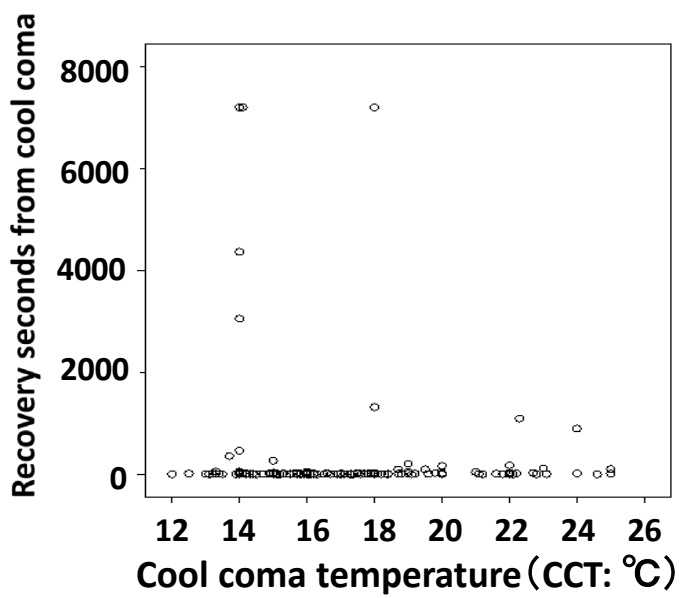

Figure 2. Relationship between recovery seconds from cool coma and cool coma temperatures in adults individuals of $H$. germanus ( $>95 \%$ ) (Pearson's test: $\mathrm{r}=0.080, \mathrm{p}=0.257$ ).

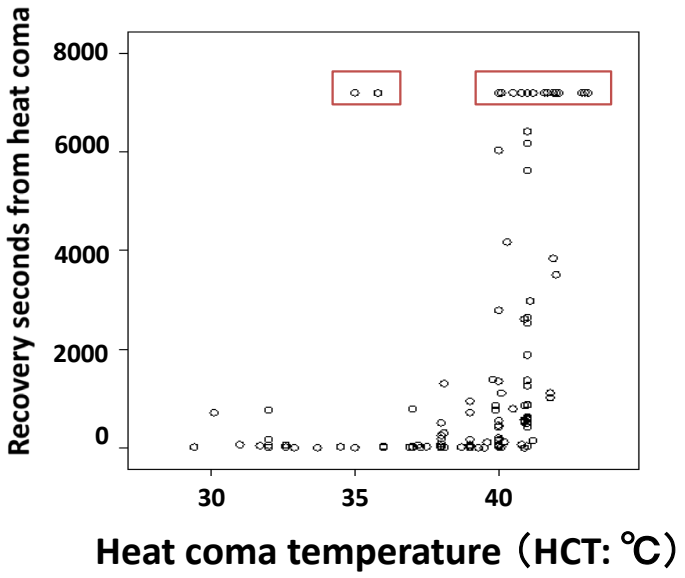

Figure 3. Relationship of recovery seconds from heat coma to heat coma temperatures in adult individuals of $H$. germanus (>95\%) (Pearson's test: $\mathrm{r}=0.522, \mathrm{p}<0.001$ ). Circles in the red squares show individuals which have been not recovered for $7200 \mathrm{sec}$ from heat coma. 
passed over R/V MIRAI, Cool Coma Temperature of $H$. gerumanus was a little lower than that before (Figure 4).

\subsection{Cross-Tolerance between Hardness to Lower and Higher Temperatures}

Correlation analysis was performed between heat tolerance and cool tolerance in the adults of Halobates germanes (Figure 5). Data sets which share the common three conditions got together to become several plots and the plots showed significant correlation between CCTs and HCTs (Figure 5). Heat Coma Temperatures were plotted on vertical axis and CCTs on horizontal axis. The three conditions were "Date when sampling were performed", "Sex" and "Days when specimens have been kept at laboratory from the sampling till the beginning of the experiments".

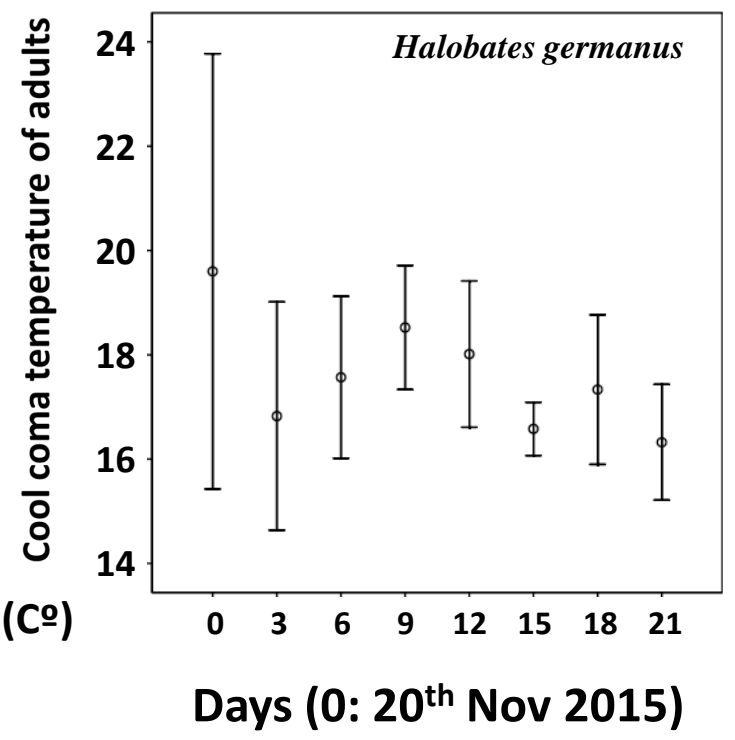

Figure 4. Change in the cool coma temperature (Mean \pm SD) at 0 day (Station 2, Sampling 2) and 3 21 days (Station 2, Samplings 3-9). From $15^{\text {th }}$ to $21^{\text {st }}$ day, Madden Julian Oscillation has passed over the R/V Mirai which were sitting at the similar position (Station 2, Samplings 2 - 9).

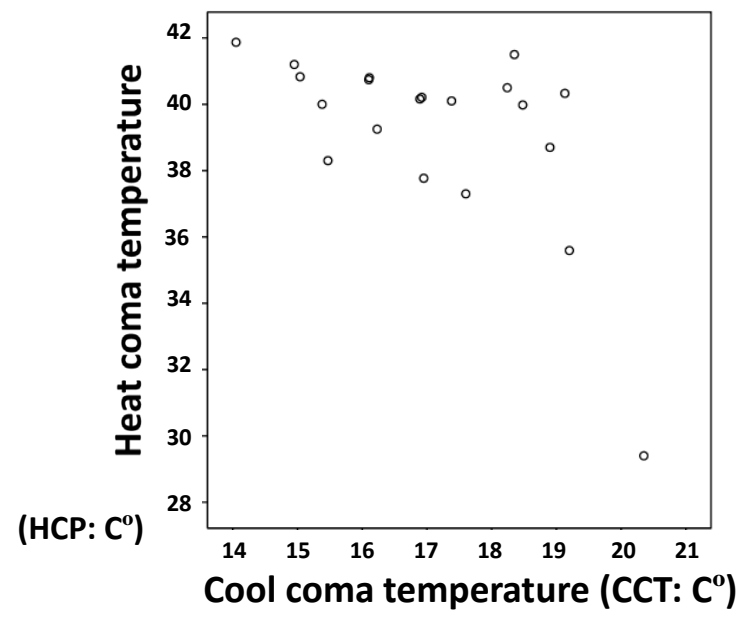

Figure 5. Significant positive correlation (Pearson's test: $r=-0.588, p=0.006$ ) between heat tolerance and cool tolerance in adult $H$. germanus inhabiting eastern Indian Ocean (Station 2, Samplings 2 - 9). 


\section{DISCUSSION}

\subsection{Distribution of Oceanic Halobates and Oceanic Dynamics in Tomini-Bay and Celebes Sea}

Extremely high density of individuals of Halobates sp. 1 is estimated to inhabit Tomini-Bay. Because samplings by IKMT-NET leaded to be under-estimated of the density due to the disturbance by the ship body during the sweeping in the back of the ship, at least several hundred-thousand or more individuals of $H$. sp per $1 \mathrm{~km}^{2}$ seems to be on Tomini-Bay which is more than $10-100$ or more times of individual density in the western Tropical Pacific Ocean and also 2 times of density than that of $H$. micans on that (208 thousands individuals on the tropical Atlantic Ocean [16]. Probably extremely smooth water surface in Tomini-Bay can be related to the high abundance of this species and also extremely high reproductive ability can be speculated to link to such complete and high density occupation without other oceanic $\mathrm{Ha}$ lobates species. From the evolutional point of view, Tomini-Bay and related inside seas in Eastern-Western Asian Islands Area can be speculated to be the original area for a newly recruitment of the originally "costal" species into the oceanic life to mean the recruitment of another oceanic new species.

\subsection{Distribution of Oceanic Halobates in the Shore Area near to the Sumatra Island in the Indonesia}

In the shore area near to the Sumatra Island, the three species of one oceanic species, Halobates germanus, and other two shore species of $H$. princeps and $H$. sp 2 were collected [15]. In the shore area of Indian sea near to the Sumatra Island and Celebes sea, oceanic species like as $H$. germanus might occupy as a main species, although they inhabit there with relatively lower population density, whereas extremely high density of a shore species like as $H$. sp 1 may occupy smaller inland seas like as the Tomini-bay because of very smooth water surface like as mirror and fruitful supply of foods there.

\subsection{Cross-Tolerance between Hardiness to Lower and Higher Temperatures}

There have been so many studies on the mechanisms which regulate the hardiness to lower or higher temperature, especially on heat shock proteins as key substances. For example, RNA interference of a heat shock protein, Hsp 70, reduces its protection role in a chilling injury to the bet armyworm, Spodoptera exigua [17]. On the tolerance to higher temperature, heat shock protein is well known to be in transcript higher than that under normal conditions in response to the exposure to heat in insects especially Drosophila $[18,19]$. There seems to be heat shock protein defense from the damage of proteins due to heat as a mechanism [20]. However, there have been rare case that the cross tolerances both to lower and higher temperatures in insects have been shown. As the rare case, a cross tolerance between higher and lower temperatures have been shown in six temperate and subtropical species belonging to the Drsophila melanogaster species group, and this tolerance can be related to the phospholipids contents especially un-saturated lipids contents [8]. Also in the oceanic sea skaters, H. micans, a positive correlation was detected between heat coma temperature and percentage of an unsaturated fatty acid, palmitoleic acid [21]. Un-saturated phospholipids contents could be effective for a physical flexibility of cell membranes in insects. In $H$. germanus, a heat shock protein and also un-saturated phospholipids contents might be related as common mechanisms both of tolerances to lower and higher temperatures in this study, although such physiological mechanisms remain to be examined in the near future.

\subsection{Madden Julian Oscillation and Resistance to Lower Temperature of Oceanic Skaters}

The special area in the tropical Indian Ocean, $5^{\circ} \mathrm{S}-10^{\circ} \mathrm{S}, 75^{\circ} \mathrm{E}-95^{\circ} \mathrm{E}$ can show intra-seasonal and greatest fluctuation in sea temperature in the world, this special area is predicted to be a site for developing a large low pressure mass due to the Madden Julian Oscillation (MJO) (Yoneyama, personal communication, [10]. Oceanic sea skaters of $H$. micans inhabiting this area show very high tolerance to higher temperatures up to about $40^{\circ} \mathrm{C}$ [14]. During the cruise of this study (MR15-04), especially during, the Research Vessel MIRAI, locating in a fixed site, $4^{\circ} \mathrm{S} 102^{\circ} \mathrm{E}$, a Madden Julian Oscillation was scheduled to pass 
over the MIRAI. So, we have tried to measure a Cool Coma Temperature of adult $H$. germanus during 3 weeks including the last week when the Madden Julian Oscillation has passed over. The sea skaters showed higher tolerance to lower temperature when it passed over. It is not clear whether this high tolerance is the result of temperature acclimation, and/or whether it is the result of genetic selection to individuals with high tolerance to lower temperatures in the oceanic sea two skaters of the oceanic two species, $H$. germanus and H. micans [2].

\subsection{Comparison of Tolerances to Lower or Higher Temperature between Oceanic Species and Shore Species of Sea Skaters}

Even in the same species of $H$. germanus, the populations inhabiting the area near to shore, $8^{\circ} \mathrm{N}$ $138^{\circ} \mathrm{E}$ which is the highest precipitation area in the world ocean show higher tolerance to lower temperature than those inhabiting the area (around $12^{\circ} \mathrm{N} 135^{\circ} \mathrm{E}$ ) far from the islands, because annual precipitation is low and surface temperature is stable around $30^{\circ} \mathrm{C}-31^{\circ} \mathrm{C}$ at the station, $12^{\circ} \mathrm{N} 135^{\circ} \mathrm{E}$ whereas surface temperature frequently can be decreased to around $25^{\circ} \mathrm{C}$ at the station, $8^{\circ} \mathrm{N} 138^{\circ} \mathrm{E}$ [6]. The difference in the tolerance is possible to due to the difference in genetic selection by temperature decrease when it is rainy and/or the difference in the intensity of lower temperature acclimation. This problem on the mechanism of the tolerance to lower temperature should be searched by several temperature acclimation experiments in near future.

\section{ACKNOWLEDGEMENTS}

We would like to thank Dr. Jun AOYAMA (Ocean Research Institute, The University of Tokyo, Chief Scientist of the cruise: KH-09-05-Leg 7) and Dr. Sam WOUTHUYZEN (Indonesian Institute of Science, LIPI, Co-Chief Scientist of this cruise) for their permission to do this study during the cruise on the R/V HAKUHOMARU, for their warm suggestion on this study, and encouragement and help throughout the cruise, KH-09-05-Leg 7 boarding on the R/V HAKUHOMARU. We also would like to thank Dr. Masaki KATSUMATA (Chief Scientist of the cruise: MR15-04, Senior Scientist, Japan Agency for Marine-Earth Science and Technology: JAMSTEC) for his permission of doing this study during the cruise boarding on the R/V MIRAI, for his warm suggestion on this study, and for encouragement and help throughout this cruise. The samplings and the experimental study were also possible due to supports from all of the crew (KH-09-05-Leg 7, Captain: Mr. Ushio FUJITA; MR15-04, Captain: Mr. Hiroshi MATSUURA) and all the scientists and the engineers from MWJ and GODI in these 2 cruises. We would like to give special thanks to them.

\section{REFERENCES}

1. Harada, T., Takenaka, S., Sekimoto, T., Nakajyo, M., Inoue, T., Ishibashi, T. and Katagiri, C. (2011a) Heat Coma as an Indicator of Resistance to Environmental Stress and Its Relationship to Ocean Dynamics in the Sea Skaters, Halobates (Heteroptera: Gerridae). Insect Science, 18, 703-711. https://doi.org/10.1111/j.1744-7917.2011.01409.x

2. Harada, T., Takenaka, S., Sekimoto, T., Ohsmi, Y., Nakajyo, M. and Katagiri, C. (2011b) Heat coma and Its Relationship to Ocean Dynamics in the Oceanic Sea Skaters of Halobates (Heteroptera: Gerridae) Inhabiting Indian and Pacific Oceans. Journal of Thermal Biology, 36, 299-305. https://doi.org/10.1016/j.jtherbio.2011.05.001

3. Harada, T., Takenaka, S., Iyota, K., Shiraki, T., Moku, M., Katagiri, C. and Koštál, V. (2013) Supercooling Points and Heat Coma Temperatures in Four Species of Oceanic Sea Skaters of the Genus Halobates (Heteroptera: Gerridae: Halobatinae). Journal of Asia-Pacific Entomology, 16, 219-222.

https://doi.org/10.1016/j.aspen.2013.01.005

4. Nakajo, M., Sekimoto, T., Emi, K., Ide, R., Wada, K., Inoue, T., Moku, M., Kostal, V., Katagiri, C. and Harada, T. (2013) Comparison of Temperature Preference for Habitat among Three Species of Oceanic Sea Skaters, Ha- 
lobates micans, H. germanus and H. sericeus. Natural Science, 5, 9-15. https://doi.org/10.4236/ns.2013.512A002

5. Furuki, T., Umamoto, N., Nakajo, M., Sekimoto, T., Moku, M., Katagiri, C. and Harada, T. (2015) Comparative Study of Cool Coma Temperature between Two Populations of Oceanic Sea Skaters, Halobatessericeus (Heteroptera: Gerridae), Located at $24-25^{\circ} \mathrm{N}$ and $138^{\circ} \mathrm{E}$ or $160^{\circ} \mathrm{E}$ in the Pacific Ocean. Trends in Entomology, 11, 55-61.

6. Umamoto, N., Sekimoto, T., Furuki, T., Nakajo, M. and Harada, T. (2015) Do Sea Skaters of Halobates Inhabiting a High Precipitation Area around the Equator Have Higher Resistance to Lower Temperatures? Trends in Entomology, 11, 119-126.

7. Baley, M., Petersen, S.O., Knigge, T., Kohler, H.R. and Holmstrup, M. (2001) Drought Acclimation Confers Cold Tolerance in the Soil Collembolan Folsomia candida. Journal of Insect Physiology, 47, 1197-1204. https://doi.org/10.1016/S0022-1910(01)00104-4

8. Ohtsu, T., Kimura, M.T. and Katagiri, C. (1998) How Drosophila Species Acquire Cold Tolerance Qualitative Changes of Phospholipids. European Journal of Biochemistry, 252, 608-611. https://doi.org/10.1046/j.1432-1327.1998.2520608.x

9. Harada, T., Ikeda, S. and Ishibashi, T. (2010a) Cross Tolerance between Heat and Cold Stress by Warm Temperate Aquarius paludumpaludum and Subtropical Aquarius paludumam amiensis, Semi-Aquatic Bugs (Gerridae, Heteroptera). Formosan Entomologist, 30, 87-101.

10. Harada, T., Sekimoto, T., Iyota, K., Shiraki, T., Takenaka, S., Nakajyo, M., Osumi, O. and Katagiri, C. (2010b) Comparison of the Population Density of Oceanic Sea Skater of Halobates (Heteroptera: Gerridae) among Several Areas in the Tropical Pacific Ocean and the Tropical Indian Ocean. Formosan Entomologist, 30, 307-316.

11. Madden, R.A. and Julian, P.R. (1971) Detections of a 40 - 50 Day Oscillation in the Zonal Wind in Tropical Pacific. Journal of Atmospheric Sciences, 28, 702-708.

https://doi.org/10.1175/1520-0469(1971)028<0702:DOADOI $>2.0 . C O ; 2$

12. Madden, R.A. and Julian, P.R. (1994) Observations of the 40 - 50 Day Tropical Oscillation: A Review. Monthly Weather Review, 122, 814-837. https://doi.org/10.1175/1520-0493(1994)122<0814:OOTDTO >2.0.CO;2

13. Marzuki, Hashiguchi, H., Kozu, T., Shimomai, T., Shibagaki. Takahashi, Y. (2016) Precipitation Microstructure in Different Madden-Julian Oscillation Phases over Sumatra. Atmospheric Research, 168, 121-138.

https://doi.org/10.1016/j.atmosres.2015.08.022

14. Harada, T., Takenaka, S., Sekimoto, T., Osumi, Y., Iyota, K., Furutani, T., Shiraki, T., Nakajo, M., Katagiri, C., Moku, M. and Koštál, V. (2012) Correlation Analysis of Heat Hardiness and Super-Cooling Point in the Oceanic Sea Skaters, Halobates. Trends in Entomology, 10, 115-124.

15. Harada, T., Furuki, T., Ohoka, W., Umamoto, N., Nakajo, M. and Katagiri, C. (2016) The First Finding of Six Instars of Larvae in Heteroptera and the Negative Correlation between Precipitation and Number of Individuals Collected in Sea Skaters of Halobates (Heteroptera: Gerridae). Insects, 7, 73th Paper: 1-11.

https://doi.org/10.3390/insects7040073

16. Andersen, N.M. and Cheng, L. (2004) The Marine Insect Halobates (Heteroptera: Gerridae): Biology, Adaptations Distribution, and Phylogeny. Oceanography and Marine Biology an Annual Review, 42, 119-180. https://doi.org/10.1201/9780203507810.ch5

17. Choi, B., Hepat, R. and KimInterferen, Y. (2014) RNA Interference of a Heat Shock Protein, Hsp70, Loses Its Protection Role in Indirect Chilling Injury to the Beet Armyworm, Spodoptera exigua. Comparative Biochemistry and Physiology, Part A, 168, 90-95. https://doi.org/10.1016/j.cbpa.2013.11.011

18. Velazquez, J.M., Sonoda, S., Bugaisky, G. and Lindquist, S. (1983) Is the Major Drosophila Heat Shock Protein Present in Cells That Have Not Been Heat Shocked? Journal of Cell Biology, 96, 286-290. 
https://doi.org/10.1083/jcb.96.1.286

19. Goto, S.G., Yoshida, K.M. and Kimura, M.T. (1998) Accumulation of Hsp70 mRNA under Environmental Stresses in Diapausing and Nondiapausing Adults of Drosophila triauraria. Journal of Insect Physiology, 44, 1009-1015. https://doi.org/10.1016/S0022-1910(97)00143-1

20. Neven, L.G. (2000) Physiological Responses of Insects to Heat. Postharvest Biology Technology, 21, 103-111. https://doi.org/10.1016/S0925-5214(00)00169-1

21. Takenaka, S., Katagiri, C., Koštál, V. and Harada, T. (2014) Heat Coma Temperature, Relative Contents of Saturated/Unsaturated Fatty Acids and Reproductive Maturation in the Oceanic Sea Skaters Halobates micans. Journal of Asia-Pacific Entomology, 17, 633-637. https://doi.org/10.1016/j.aspen.2014.06.004

Submit or recommend next manuscript to SCIRP and we will provide best service for you:

Accepting pre-submission inquiries through Email, Facebook, LinkedIn, Twitter, etc.

A wide selection of journals (inclusive of 9 subjects, more than 200 journals)

Providing 24-hour high-quality service

User-friendly online submission system

Fair and swift peer-review system

Efficient typesetting and proofreading procedure

Display of the result of downloads and visits, as well as the number of cited articles

Maximum dissemination of your research work

Submit your manuscript at: http://papersubmission.scirp.org/

Or contact ns@scirp.org 